\title{
Editorial
}

\section{The dismantling of our future}

Latino Studies (2010) 8, 299-303. doi:10.1057/lst.2010.39

A man's admiration for absolute government is proportionate to the contempt he feels for those around him.

(De Tocqueville, 1955[1856])

When it comes to respecting rights, the country's downward spiral is clearly intensifying. In the past 6 months alone, for example, we have witnessed blatant attacks on rights and human dignity in US society, including,

- the enactment of Arizona's SB 1070, officially promoting racial profiling;

- the establishment of officially endorsed censorship through HB 2281, which bans ethnic studies classes and textbooks in Arizona's public schools;

- the official condoning of the removal of teachers who speak English with heavy accents from Arizona's classrooms;

- multiple efforts to begin the process of repealing the fourteenth amendment through proposals to deny citizenship to the US-born children of undocumented immigrants;

- frontal attacks on religious freedom and rights, in the form of a "debate" on the building of a mosque near New York City's "ground zero," which has led, in the words of William River Pitts, to a growth in hate crimes and violent threats against Muslims; ${ }^{1}$

- ongoing attacks on equal rights for gays and lesbians through the challenge to the judge's recent ruling on Proposition 8;

- the arbitrary dismissal of a government official, Shirley Sherrod, in Georgia, who was forced to step down from her post as Director of Rural Development, without recourse to a fair hearing, because of slanderous lies posted on the internet.

To these we must add the ongoing abuses of power through immigration raids, and in detention and deportation centers, as well as the escalating hate crimes and violence, particularly but certainly not only, against Latino/as in the United States.

The test of a just society lies in the protections afforded to its least fortunate members. Yet in the case of the United States, how can these even be measured?

1 In River Pitts' (2010) words, "Mosques have been firebombed. A Muslim cabdriver in New York City was savagely slashed by a man screaming anti-Islam epithets. A Sikh man was punched in a store for wearing a turban, even though he was as 
Muslim as a church steeple. The controversy over the Cordoba House project has inspired a rash of threats against the Imam in charge, the Muslims involved, and the building itself."

2 This is to say nothing of course about the ongoing web of deceit and lies concerning, for example, BP's environmental catastrophe, the bank profits, the withdrawal of the US troop presence in Iraq; Blackwater's “30 false fronts" that obtained "millions of dollars in federal government contracts" (Risen and Mazzetti, 2010), and the President's "Muslim" faith (Pew Research Center, 2010).
After all, today, only lies surround every attack, every act of violence, every threat against the rights of all in this nation; and there are lies, it seems, about everything - about the causes and consequences of immigration (the only reason "they" come is to "drop their 'anchor babies' on American soil"), about the resulting growth in crime and violence along the border region (yet as research shows, Arizona today, for example, has the lowest crime rates since 1983); ${ }^{2}$ about the jobs Latino/as ostensibly take from US citizens - they don't! (cf. Factcheck.org, 2010); about the ever-growing numbers of undocumented (the numbers are instead "down sharply since mid-decade" (Passel and Cohn, 2010).

The result is that the country today is so entangled in disentangling the lies, that we now seem to be living in a parallel world, far removed from reality ... .

Concerns about what the presence of Latino/as, regardless of their legal status, is doing or not doing to US society are for the most part - not matched in the media with an equal concern about the impact and consequences for immigrants of the decline in the society's awareness of the need to protect the rights of all. Martha Caminero Santangelo's article in this issue analyzes recent novels that seek to bring attention to the "human costs of inhuman border and immigration policies." Her focus is the trauma created among Latino/as by nativism, the emphasis on cheap and exploitable labor, and the border enforcement initiatives that continue to imperil the lives of migrants crossing the desert; she also points to the construction of collective identities responding to the contemporary context in which Latino/a migrants live their lives. Douglas S. Massey and Julia Gelatt's article further adds to the context in which Mexican immigrants are forced to live their lives. Noting that Mexican immigrant wages have actually stagnated for decades, Massey and Gelatt emphasize that in 2007 these stood roughly at 1960 s levels. They point to the shifts in the political economy to present evidence to explain this stagnation in terms of the consequences, for immigrants, of declining labor rights and the concomitant increase in practices of discrimination and exclusion.

Practices of discrimination and exclusion, of course, are not limited to the immigrant experience. Two articles in this issue analyze the experiences of US Latino/a citizens, in an effort to nuance and hence act as a corrective to the available scholarly literature and current public discourse shaping perceptions about Latino/as in the United States.

Inmaculada Lara-Bonilla provides a careful analysis of the now classic collective memoir, Getting Home Alive, (1986) coauthored across two generations, by mother and daughter Aurora Levins Morales and Rosario Morales. The significance of Lara-Bonilla's article lies in her insistence on exploring the internal diversity and hybridity of Puerto Rican cultural identity as reflected in Getting Home Alive, in order to better understand "the variety of motives for migration and its relationship with the phenomenon of exile." Firmly grounded in this still largely neglected historical text, Lara-Bonilla 
argues that closer attention to the multiplicity of Puerto Rican identities is essential to better understand the Puerto Rican experience, as well as the nature of displacement itself and its role in constructing the individual and collective identities of a community.

In the context of the ongoing clouding of complexity of the Latino/a experience, Latino/a studies scholarship's emphasis on the nuances that ultimately shape and diversify the experiences of the community can serve as a corrective to the stereotypes, ignorance, and miseducation that currently underlies and shapes public discourse and perceptions. Thus, Robert J. Durán addresses misconceptions about Latino/a gangs by focusing on the issue of drug dealing. His article both describes and explains the reasons and conditions under which drugs become (or not) a part of the gangs' raison d'être. Exploring the composition and context for the emergence and existence of gangs involved in drug sales, Durán cautions that "[t]here is a tremendous power in the ability to confer the labels of gang and drug dealer to large groups of individuals who don't empirically meet these criteria." Thus, he notes that in cities such as Ogden, Utah and Denver, Colorado where he conducted his comparative study, “most gangs ... are not organizations for profit.” Durán's ethnographic "insider" research both acknowledges and goes beyond initial factors such as "friendship, protection, and status in the barrio" that are understood as motivating inner-city Latino/a youth to join gangs. Instead, in addition to the specificities of the gangs' membership, he also focuses on the importance of assessing their experience with, and the responses of, law enforcement, the differentiated organizational structure of the gangs, and the context of drug sales. This multiple approach allows him to nuance the literature's insistent focus on the gang's level of organization as the key determinant for gang activity. In addition, Durán also contextualizes his assessment of these factors in terms of the social and economic specificities of the barrios that contribute to shaping the emergence, experience, and types of gangs in his research sites, concluding that in Ogden and Denver, "[g]angs and drug dealing were largely two separate issues despite the stereotype in both cities that they are combined."

The stark invisibility of the conditions under which Latino/as live their lives in the barrios, reinforced by racial discrimination and social exclusion, undoubtedly contributes to strengthening misconceptions about Latino/as' daily-life experiences in US society - whether in the context of gang formation and activity, or in the institutions of the broader mainstream society. In the continued absence of information and scholarship, the multiple distortions and societal stereotypes undoubtedly become yet another layer in the ongoing obfuscation of the social reality structuring Latino/as' experiences in US society today.

The two essays in this Issue's VIVENCIAS: Reports from the field section vividly seek to inform and portray to the broader US community some of the human costs of the ongoing willful blindness and passivity toward the deadly injustices that individuals continue to suffer as a result of this nation's mis- 
3 As Henry Giroux (2010) describes "Shaping the neoliberal framing of public and higher education is a corporate-based ideology that embraces standardizing the curriculum, supporting informed and inhumane immigration policies. Brian Rich's report from Lexington documents his informal talk at a Kentucky bar in which he discussed what he defines as the "death prisons for the innocent." His essay portrays the horrifying last months and death of Ana Romero, an immigrant woman who died alone in a jail house in Frankfort Kentucky, where, despite the protests of family and friends, she was wrongfully detained. From Mexico, Joel Medina writes of the circumstances that led to his 12-year imprisonment and the impact on his life today, of his subsequent deportation to Mexico, a country he barely remembered, having moved at the age of 4 to the United States where he grew up and where his entire family still lives. One can only wonder what would have become of his life and that of the thousands of other Latino/a youths deported today, had they been allowed to have the opportunities to participate on a more equal footing in this society. Instead, the lack of adequate schools, the failure to pass immigration reform and the DREAM Act, and, perhaps most importantly, the societal unwillingness to affirm the nation's discourse and values of humanity and fairness today continue to destroy people's lives, hopes, and dreams.

More detailed and nuanced information grounded in research on the realities of the Latino/a experience in the United States, coupled with a strong, renewed societal commitment to a public education grounded in critical thinking, could begin to provide an antidote for the ignorance that is contributing to the deaths and the suffering of so many thousands of Latino/as like Ana Romero and Joel Medina, and thus comprise an essential component of any real movement for social change. It is in this context too that the negative consequences of the government's continued inaction - on the Dream Act; on implementing humane and comprehensive immigration reform; on laws such as Arizona's HB 2281, resulting in the censorship of Ethnic Studies courses and books in public schools; on reigning in educational initiatives grounded in market forces and privatization; or on correcting misguided policies such as "No Child Left Behind" - can be clearly seen. One obvious result is the growth of the school-toprison pipeline and the creation of a future grounded in fear and the death of hope, particularly among poor and minority youth. Indeed, we are witnessing today the unprecedented dismantling of the nation's education system at all levels, with consequences not only for the least/less fortunate in our society, but for the entire population. ${ }^{3}$

The overall result is an ever-expanding trend toward the criminalization of all social issues, while social protections are either eliminated or fatally weakened, as witnessed in the increasing incarceration of young people, the modeling of public schools after prisons, and state policies that bail out investment bankers, while simultaneously leaving the middle and working classes increasingly destitute.

In the face of the current economic meltdown, anger is replacing critique, ignorance is informing politics, and American society tends to limit choices, legitimize political illiteracy, and promote violence (Hernández, 2010). This 
requires a response adequate to confront the threat to the very fabric of our society: a true Resistance that, as aptly pointed out by Ramzy Baroud (2010), "is not a band of armed men hell-bent on wreaking havoc ... True resistance is a culture. It is a collective retort to oppression," - one which Latino/a Studies scholars and intellectuals must sign on to as they practice their vocation of upholding human dignity and freedom.

Saludos!

\section{References}

Baroud, R. 2010. Beyond Violence and Nonviolence: Resistance as a Culture. Truthout, 8 August, http://www.truth-out.org/beyond-violence-and-nonviolence-resistancea-culture61623.

De Tocqueville, A. 1955[1856]. The Old Regime and the Revolution. New York: Anchor books.

Factcheck.org. 2010. Does Immigration Cost Jobs? Economists Say Immigration, Legal or Illegal, Doesn't Hurt American Workers, May 13, http://www.factcheck.org/2010/05/ does-immigration-cost-jobs/.

Giroux, H.A. 2010. The Disappearing Intellectual in the Age of Economic Darwinism. Truthout/OpEd, 12 July, http://www.truth-out.org/the-disappearing-intellectual-ageeconomic-darwinism61287.

Hernández, T.K. 2010. Black-on-Mexican Violence in Staten Island, NY: The Untold Tale of Turf Defense. New York: National Institute for Latino Policy Guest Commentary, 24 August, http://archive.constantcontact.com/fs057/1101040629095/archive/1103635 857372.html.

Passel, J. and D. Cohn. 2010. U.S. Unauthorized Immigration Flows Are Down Sharply Since Mid-Decade. Pew Hispanic Center, 1 September, http://pewhispanic.org/reports/ report.php? ReportID=126.

Pew Research Center. 2010. Growing Number of Americans Say Obama is a Muslim: Religion, Politics and the President. http://people-press.org/report/645/.

Risen, J. and M. Mazzetti. 2010. 30 False Fronts Won Contracts for Blackwater. The New York Times, 3 September, http://www.nytimes.com/2010/09/04/world/middleeast/ 04blackwater.html.

River Pitts, W. 2010. Hatred and Stupidity... But I Repeat Myself. Truthout, 4 September, http://www.truth-out.org/hatred-and-stupidity\%E2\% 80\% A6but-i-repeat-myself62916.

\author{
Suzanne Oboler \\ John Jay College of Criminal Justice-CUNY, \\ New York, NY, USA. \\ E-mail: soboler@jjay.cuny.edu
}

top-down management, implementing more courses that promote business values and reducing all levels of education to job training sites .... Such modes of education do not foster a sense of organized responsibility central to a democracy. Instead, they foster what might be called a sense of organized irresponsibility a practice that underlies the economic Darwinism, public pedagogy and corruption at the heart of both the current recession and American politics." 